\title{
自溶合金溶射部材の疲労強度に及ぼす基材表面粗さの影響*
}

\author{
曙 \\ 紘之*1, 牧田 秀 彦*2, 小茂鳥 潤*3 \\ 清水 真佐男*3, 福 本昌 宏*4

\section{The Effect of the Surface Roughness of Substrate on Fatigue Strength of Thermally Sprayed Steel with Ni-based Self-Fluxing Alloy} \\ Hiroyuki AKEBONO*5, Hidehiko MAKIDA, Jun KOMOTORI, \\ Masao SHIMIZU and Masahiro FUKUMOTO \\ ${ }^{* 5}$ Graduate School of Science and Technology, Keio University, \\ 3-14-1 Hiyoshi, Kohoku-ku, Yokohama-shi, Kanagawa, 223-8522 Japan

\begin{abstract}
To investigate the effects of the surface roughness of substrate on fatigue properties of a thermally sprayed specimen, three types of substrates with different surface roughness were prepared. After thermal spraying, two types of post heat treatments (fusing) were performed by an induction heating system and a vacuum furnace. Then rotational bending fatigue tests were carried out. Two types of fatigue fracture mechanisms were observed; in the former was an interface delamination mode and in the latter was a coating fracture mode. In the case of the interface delamination mode, substrate roughness strongly affected the fatigue strength of the sprayed specimen; the rougher the substrate surface, the higher the fatigue strength. This is because rougher substrate leads to higher adhesive strength between the coatings and the substrate. In the case of the specimen failure in the coating fracture mode, the surface roughness of the substrate had no remarkable effect on the faigue strength of the sprayed specimen.
\end{abstract}

Key Words: Fatigue, Fracture Mechanism, Ni-Based Self-Fluxing Alloy, Fusint Time, Surface Roughness

\section{1. 緒言}

比較的安価な材料に対して高性能な合金を溶射する ことにより，その耐食性や耐熱性, 対摩耗性の向 上(1) (4) を図る溶射法は, 簡便かつローコストな表面 処理法の一つとして近年注目されている.しかしなが ら, 溶射が施された部材の疲労特性に関する研究(5) (8) はあまり行われていないのが現状である．そこで著者 らは, 溶射部材の疲労に対する信頼性と安全性の確保 のため, 特に高疲労強度が期待できる自溶合金溶射部 材について一連の研究(9) (14)を行っている.

自溶合金の溶射法は, 大きく三つの工程に分けられ る.まず，基材の粗面化を目的としたブラスト処理， 次に溶射材料を被覆する溶射処理, そして最後に被覆 された皮膜を溶融・半溶融状態に再加熱し, より良好 な性状の溶射皮膜を形成する再溶融処理(以下フュー ジング)である，自溶合金溶射過程特有の処理である

\footnotetext{
* 原稿受付 2004 年 3 月 30 日.

*1 正員, 慶應義塾大学大学院理工学研究科 $(-223-8522$ 横浜 市港北区日吉 3-14-1).

*2 慶應義塾大学大学院理工学研究科.

*3 正員, 慶應義塾大学理工学部.

*4 正員, 豊橋技術科学大学工学部 ( 441-8580 豊橋市天伯町 雲雀ケ丘 1-1)

E-mail : te $04861 @$ educ.cc.keio.ac.jp
}

フュージングは, 皮膜組織を均質化し, 皮膜中の空孔 を除去することが可能であり，さらに皮膜-基材間に 拡散層を形成して, 界面の冶金的な結合力を増大させ るといった利点がある、しかしながら，このフュージ ングは通常トーチによる手作業で行われるため, 処理 時間や温度に関して作業者の経験や勘に頼るところが 多い. その結果, 皮膜の疲労寿命や強度に大きなばら つきが発生することとなり, 十分な疲労信頼性の確保 が難しいという問題点が残されている( ${ }^{(9)}$.

著者らはこれまでに, フュージング時の溶射皮膜温 度のばらつきの抑制を目的として, 温度制御が可能な 雲囲気炉, 真空炉および高周波誘導加熱装置を用いた フュージングを提案し，その方法で処理したCo 基自 溶合金溶射部材の疲労特性について研究を行っ た 御することにより, 疲労寿命のばらつきの抑制が可能 となること, また, 基材と比較して疲労強度を飛躍的 に向上し得ることを明らかにしたまた前報(14)では, $\mathrm{Ni}$ 基自溶合金溶射部材の疲労特性に及ぼすフュージ ング時間の影響について研究を行い, その結果, 長時 間のフュージングは逆に皮膜組織の不均質化をもたら し疲労強度低下の要因となること，そのため自溶合金 溶射部材の疲労強度向上のためには短時間フュージン 
グが望ましいが，その際，フュージング時間が短すぎ ると, 基材一皮膜間の密着力が不十分なため, 疲労負荷 過程において皮膜がはく離を生じて, 疲労強度はほと んぞ向上しないことを明らかにした。

以上の研究は溶射処理後のフュージングに関するも のであるが，自溶合金溶射部材の疲労特性に影響を及 ぼすと考えられる今ひとつの重要な要因にブラスト処 理条件がある.ブラスト処理によって形成される基材 の表面山凸は, 皮膜-基材界面の密着力に影響を及ほ すことが知られているが，それらに関する研究のほと んどがせん断形はく離等を利用した静的負荷下での界 面密着強度試験(15)(16) にとどまっており, 繰返し応力 下での疲労特性に及ぼす基材表面凹凸の影響について の研究例はない。.また, 疲労負荷過程において皮膜一 基材界面ではく離が生じた溶射部材の疲労強度は, 基 材の疲労強度に支配されることがわかっており ${ }^{(14)}$, ブ ラスト処理により形成された基材表面の山凸は溶射材 の疲労強度に大きく影響を及湾すものと考えられる。 このような観点から，本研究ではブラスト処理条件を 変化させた異なる表面粗さを有する基材に対し，同一 条件で溶射処理およびフュージングを施し，これらに 対し疲労試験を行うことにより，自溶合金溶射部材の 疲労特性に及ほすす基材表面粗さの影響について検討・ 考察を加えた。

\section{2. 供試材および実験方法}

$2 \cdot 1$ 供試材の準備 基材として機械構造用鋼 S 35 C を用いた。まず同材を図 1 に示す砂時計形試 験片に機械加エした後, $\mathrm{R}$ 部表面をエメリー紙 （\#400〜＃ 2000)，およびアルミナ粉末 $(0.3 \mu \mathrm{m})$ により 鏡面状に研磨した。その後, 粒径の異なる 2 種類のス チールショットにより表 1 に示す条件でブラスト処理

Table 1 Blast process condition

\begin{tabular}{ccccc} 
Material & Distance & $\begin{array}{c}\text { Shot } \\
\text { Time }\end{array}$ & $\begin{array}{c}\text { Shot } \\
\text { Pressure }\end{array}$ & $\begin{array}{c}\text { Particle } \\
\text { Size }\end{array}$ \\
\hline Steel grit & $100 \mathrm{~mm}$ & $60 \mathrm{sec}$ & $0.6 \mathrm{MPa}$ & $\begin{array}{l}\text { A: } 0.7 \sim 1.0 \mathrm{~mm} \\
\text { B: } 0.3 \sim 0.5 \mathrm{~mm}\end{array}$ \\
\hline
\end{tabular}

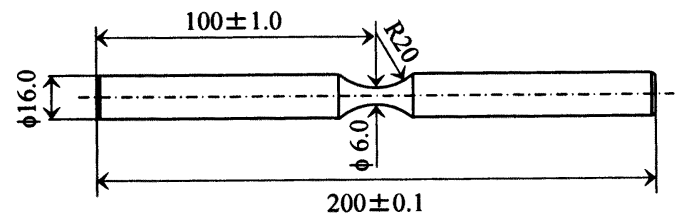

Fig. 1 Specimen geometry
を施した。さらに，ブラスト処理を施さない鏡面状態 の試験片を別に用意して, 計 3 種類の異なる表面粗さ を有する試験片を準備した。これらに対し，表 2 に示 す化学成分を有する $\mathrm{Ni}$ 基自溶合金をガスフレーム法 により溶射した，溶射処理条件を表 3 に示す。

溶射処理後, すべての試験片に対し, 保持時間の異 なる 2 種類のフュージングを施し，皮膜一基材界面に 形成される拡散層厚さを変化させた状態で以下に述べ る実験を行った。なお，保持時間を 200 秒とした短時 間フュージングには高周波誘導加熱装置(加熱速度 $5{ }^{\circ} \mathrm{C} / \mathrm{s}$ )を，また保持時間 0.5 時間の長時間フュージン グには真空炉 $\left(500^{\circ} \mathrm{C} / \mathrm{h}\right)$ を用い, その際保持温度は, $\mathrm{Ni}$ 基自溶合金の融点が $1040^{\circ} \mathrm{C}$ あ゙ることを考慮して $1010^{\circ} \mathrm{C}$ とた。なお，この到達温度の決定にあたって は, 予備実験として, 真空炉中で 990, 1000,1010 , $1020^{\circ} \mathrm{C}$ で各 4 時間フュージングを施した試験片の皮 膜組織の様相を観察し, それらの中で皮膜が溶融して 消失せず，かつ溶射皮膜内の空孔の量が最小となる温 度として $1010^{\circ} \mathrm{C}$ 選定した。 以下，基材表面の粗い 順に A series, B series, C series と称し，それぞれに おいてさらに，溶射処理ならびにフュージングを施し た試験片を $\mathrm{A}+$ spray series, B+spray series, $\mathrm{C}+$ spray series と称することにする．また，高周波誘導 加熱装置を用いた短時間フュージングの場合を(I), 真空炉による長時間フュージングの場合を $(\mathrm{V})$ と末尾 に記して,フュージングの長短を区別することとす る.また比較材として, シリーズごとに, 溶射処理を 施さない基材のみの試験片も別に準備した。なお，こ の基材のみの試験片には, フュージングの場合と熱履 歴をそろえる目的で $1010^{\circ} \mathrm{C}, 4$ 時間の焼なましを施し ており，これによりブラスト処理による基材表面の加 工硬化抢よび残留応力の影響はほほ取り除かれると考

Table 2 Composition of $\mathrm{Ni}$-based self-fluxing alloy powder

\begin{tabular}{cccccc}
$\mathrm{Ni}$ & $\mathrm{Cr}$ & $\mathrm{B}$ & $\mathrm{Si}$ & $\mathrm{Fe}$ & $\mathrm{C}$ \\
\hline Bal. & 14.7 & 2.96 & 4.40 & 2.67 & 0.60 \\
\hline & & & & & (wt,\%)
\end{tabular}

Table 3 Gas frame spraying condition

\begin{tabular}{ccc}
\hline Operating gas & $\begin{array}{c}\text { oxygen } \\
\text { acetylene }\end{array}$ & $\begin{array}{c}: \\
\text { act } 103 \mathrm{kPa}, 35 \mathrm{kP}\end{array}, 35 \mathrm{~min} . \mathrm{min}$. \\
\hline Pre-heating time & $10 \mathrm{~s}$ \\
Spray time & $30 \mathrm{~s}$ \\
Spray distance & $200 \mathrm{~mm}$ \\
Rotating speed of specimen & $300 \mathrm{rpm}$ \\
\hline
\end{tabular}


えている。

$2 \cdot 2$ 実験方法 疲労試験は, 小野式回転曲げ疲 れ試験機 $(3000 \mathrm{rpm})$ を用いて, 室温大気中で行った. 試験片としては, フュージングを施した供試材を, 図 2 に示すように皮膜厚さ $1 \mathrm{~mm}$ に機械加工後, 前述 の基材と同一条件の研磨法により鏡面状に仕上げたも のを用いた. 疲労試験後, 破断したすべての試験片に 対して走査形電子顕微鏡 (SEM) による破面観察を行 い, 疲労破壊起点部を特定するとともに破壊メカニズ ムを調べた.

溶射皮膜中の空孔率は, 走査形レーザ顕微鏡による 皮膜部分の観察画像(倍率 100 倍) を画像処理により二 値化した画面上の空孔部分の面積率として算出した. また, 拡散層厚さの測定には, エネルギー分散型 $\mathrm{X}$ 線 分光法 $(\mathrm{EDX})$ を用い, 検出元素として $\mathrm{Fe}$ (基材からの 拡散元素) および $\mathrm{Ni}$ (皮膜からの拡散元素)を選び, 皮 膜-基材間を半径方向に直線上で分析した両元素の X 線強度分布の立上がり部の幅を測定して拡散層厚さと した.

\section{3. 実験結果および考察}

$3 \cdot 1$ 基材表面粗さ 本研究では, ブラスト処理 により基材表面に形成される表面粗さの指標に平均粗 さ $R_{a}$ ，および最大粗さ $R_{y}$ を用いた，触針式表面粗 さ計により, 各シリーズの基材表面粗さを測定した結 果を図 3 に示す. なお, 平均粗さ $R_{a}$, 最大粗さ $R_{y}$ と もに各シリーズに対して 30 点測定した場合の平均值

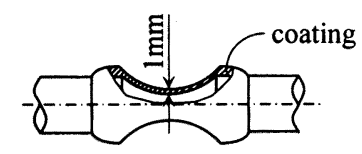

Fig. 2 Schematic illustration of sprayed coating

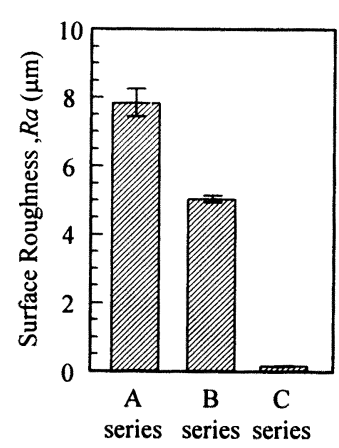

(a) $R_{a}$

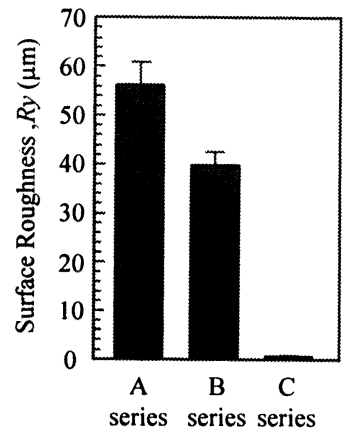

(b) $R_{y}$
Fig. 3 Result of surface roughness
を示している.

図 3 より， $R_{a}$ および $R_{y}$ ともに, $\mathrm{A}$ series $>\mathrm{B}$ series $>C$ series の順に大きな值を示しており, 本研 究の目的である異なる表面粗さを有する基材が準備さ れていることが確認された。

\section{$3 \cdot 2$ 皮膜の機械的特性, 空孔率, 拡散層厚さ 皮} 膜の弾性率は，部材内の応力分布状態にも影響を及ほ すパラメータであり，また皮膜の硬さ，および皮膜中 の溶射欠陥の寸法や量は溶射部材の疲労強度を直接支 配する要因と考えられる(9)(11). さらに, フュージング により皮膜-基材界面に形成される拡散層厚さは, 界 面密着力に大きく影響することから, 前報(13) で示し たとおり, 自溶合金溶射部材の疲労特性を支配する重 要なパラメータである.そこでまず, 溶射皮膜の弾性 率, 硬さ, 空孔率および拡散層厚さを測定した。

弾性率の測定は, 最小径部に皮膜部分のみを残して 図 4 に示す形状に機械加工した中空試験片を用いて前 報(14) と同様な方法で行った. なお, 引張試験片の作 製にあたり，基材にブラスト処理を施したものは中空 試験片への加工が困難であったため, 引張試験は基材 表面を鏡面状に研磨した C+spray seriesについての み行った. また硬さ, 空孔率, 拡散層厚さの測定結果 はそれぞれ 30 点平均を表しており, 各シリーズごと で大きな相違は確認されなかったため, 代表例として $C+$ spray series の測定結果を示している. 表 4 に測 定結果を示す.

表 4 から, 皮膜硬さ, 空孔率, 縦弾性係数に関して は, フュージング時間の長短によらずほぼ同程度の值 を有していることがわかる，また，拡散層厚さについ ては, 前報 ${ }^{(13)}$ と同様, フュージング時間の長い場合

Table 4 Effect of fusing on sprayed coating

\begin{tabular}{ccc} 
& C+spray(I) & C+spray(V) \\
\hline Young's modulus & $267 \mathrm{GPa}$ & $256 \mathrm{GPa}$ \\
\hline porosity & $0.1 \%$ & $0.6 \%$ \\
\hline Vickers Hardness(1.96N) & 747 & 704 \\
\hline Diffusion layer thickness & $8 \mu \mathrm{m}$ & $22 \mu \mathrm{m}$ \\
\hline
\end{tabular}

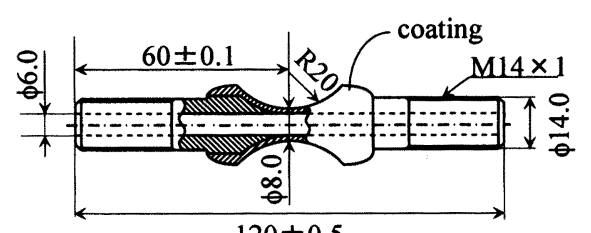

Fig. 4 Tensile test specimen 
に，より厚い拡散層が形成されることが確認された。

$3 \cdot 3$ 自溶合金溶射部材の疲労強度に及ぼす基材表 面粗さの影響(短時間フュージング) まず短時間フ ユージングを施した溶射材についての疲労試験結果を 図 5 に示す。図の縦軸は，皮膜と基材の弾性率の相違 を考慮に入れずに，試験片全体を均質材とみなして皮 膜部を含んだ試験片直径から計算した表面の公称曲げ 応力を表している.

図 5 において,まず, 基材のみの疲労試験結果(白抜 きプロット)に注目すると, 表面粗さの粗いほど疲労 強度が低下していることがわかる。次に，溶射材の疲 労試験結果(ソリッドマーク)から，すべてのシリーズ において, 基材に比べて大幅に疲労強度が向上してい ることが確認できる.

次に, 破断した各試験片に対して破壊起点部に注目 して破面観察を行った. 代表例として図 6 に $\mathrm{A}+$ spray $(\mathrm{I}) \operatorname{series} と \mathrm{C}+\operatorname{spray}(\mathrm{I}) \operatorname{series} の$ 観察結果を示 す.

溶射部材の疲労破面形状に関するこれまでの研 究(11) (14) を参考にすると, 溶射皮膜により被覆された 基材が図 6 のような疲労破面を示すのは, 疲労負荷過 程において皮膜-基材間ではく離が生じ，それに伴い 露出した基材表面を起点とした疲労き裂が発生, 進展

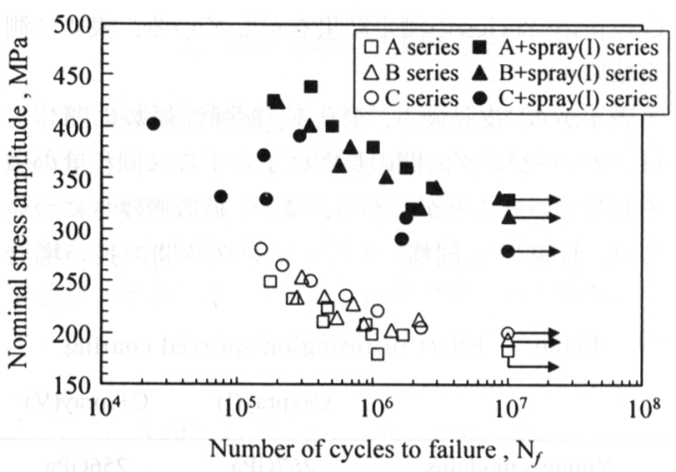

Fig. 5 Result of fatigue tests

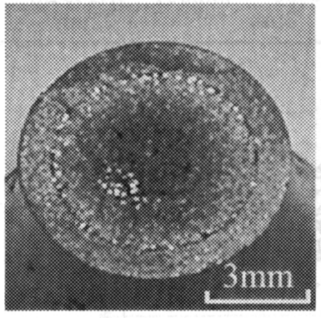

A+spray(I) series

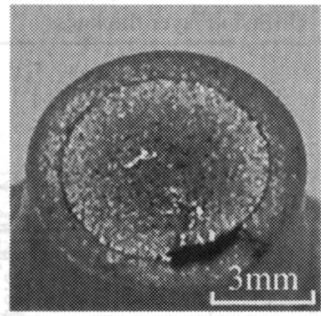

$\mathrm{C}+$ spray $(\mathrm{I})$ series
Fig. 6 Result of Microscopic observations
し, 最終破断に至るという疲労破壊プロセスが存在し ていたことを示している. 後に示す界面近傍の詳細な 観察結果(図 8)においても，皮膜-基材間のはく離が確 認されている.このような破壊形態を本論文では界面 はく離形と称することにする.

破面観察より，破壊起点部が基材表面であると考え られるので, 次に実際の疲労破壊起点である皮膜-基 材界面位置での曲げ応力值を求めて, それと疲労寿命 との関係として先の疲労試験結果をプロットし直すと 図 7 のようになる．破壊起点部の曲げ応力值の計算に あたっては, 皮膜と基材の縦弾性係数の相異を考慮に 入れた FEM 解析によりその值を算出した。 なお，先 に示した基材のみの疲労強度を示す図 5 の白抜きプロ ットの結果はここでは実線および破線で示されてい る.

図 7 より，破壊起点位置での応力值で表した溶射材 の疲労強度は, 基材の疲労強度に近いレベルにあるこ とがわかる。このことは，溶射材の疲労強度に溶射皮 膜の特性が反映されずに，基材の疲労強度によって溶 射材の疲労強度が支配されることを意味している。こ こでさらに細かく基材のみの試験片と溶射材試験片の 場合について, それぞれ基材表面粗さの変化に伴う疲 労強度の変化に注目すると, まず, 基材のみの試験片

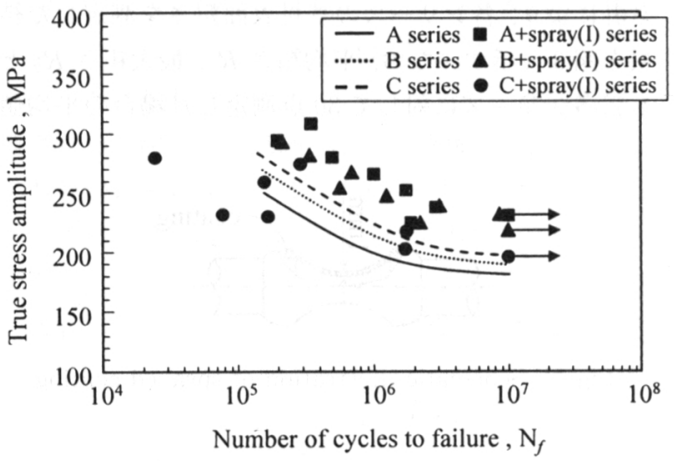

Fig. 7 Result of fatigue tests

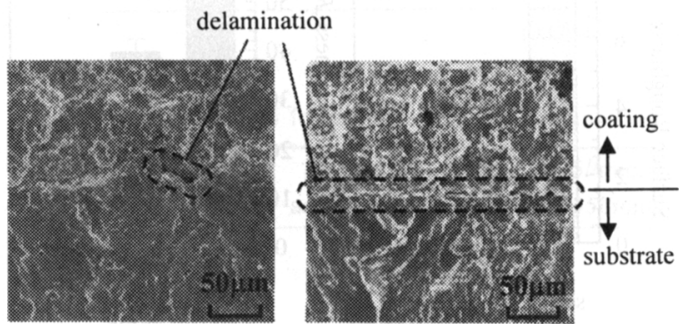

A+spray(I) series

$\mathrm{C}+\operatorname{spray}(\mathrm{I})$ series

Fig. 8 SEM observations of the interface 
の場合には, 前述のように, 基材表面が粗いほど疲労 強度は低くなる(図 5)のに対して, 溶射材の場合には 逆に, 基材表面が粗いほどむしろ高い疲労強度となっ ていることがわかる.そこで次に，この原因について 調べるため, 各シリーズの皮膜-基材界面近傍を SEM により詳細に観察した。代表例として基材表面の最も 粗い $\mathrm{A}+\operatorname{spray}(\mathrm{I})$ series と, 基材表面が鏡面状態の C + spray (I) series に関する観察結果を図 8 に示す.

図 8 より,C+spray (I) series では, 界面全周にわた ってはく離が生じているのに対して, A+spray(I) series でははく離は局所的に生じていることが観察さ れた。 また, 図6の $\mathrm{A}+\operatorname{spray}(\mathrm{I})$ series における界面 近傍の破面についてさらに詳細に観察すると，局所的 に脆性破壊に見られるようなリバーパターンが確認さ れた(図 9). 室温大気中にもかかわらず, 局所的な脆 性破壊が起こることは, このような界面近傍では基材 部が強い変形拘束を受け, 塑性変形が生じにくい状態 で破壊が起こったことを示唆するものである．またこ のことは, A+spray (I) seriesにおいては, 皮膜と基 材が局所的に強固な密着状態にあったことを示すもの である。このような脆性破壊部が観察される箇所は, $\mathrm{A}+\operatorname{spray}(\mathrm{I})$ seriesにおいて最も多く, 次いで B十 spray (I) series では少量ながらもその存在が確認され たものの, C+ spray(I) seriesにおいては, 全く認めら れなかった。

つまり, 基材表面の粗い溶射材ほど, 皮膜一基材界面 が強固に密着し，塑性変形が起こりにくい箇所が多く 存在してすべり誘起形の疲労き裂が発生しにくい状態 であったことが，基材表面の粗い溶射材ほど高い疲労 強度を示した理由であると考えられる。

次に, 同一の溶射処理およびフュージングが施され たにもかかわらず, 基材-皮膜の密着状態に上述のよ うに差異が生じる要因について検討する.

一般に，基材一皮膜界面の密着強度を決定する因子 としては，（i 機械的かみつき力(アンカー力)，(ii）

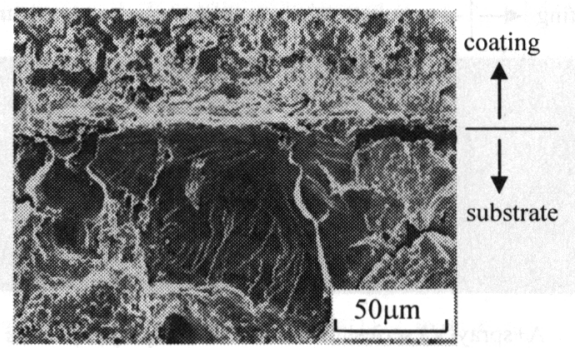

Fig. 9 SEM observations of interface
基材-皮膜界面に形成される拡散層による治金的結合 力，(iii) 皮膜と基材の物理吸着力であると考えられ る(17).

まず,第一の機械的かみつきによる密着力に関して は, 表面粗さが粗いほど増大することが知られてお $り^{(15)(16)}$, 図 3 の結果からわかるように, 本研究で用い た試験片については, A>B $>C$ series の順で界面密 着力が強いことが容易に想像される. 第二の要因とし ての治金的結合力に関しては, 本研究の場合, すべて 同一条件でフュージングを施しているため, 各シリー ズ間での差異はないと考えられる。さらに物理吸着力 に関しては, ブラスト処理時の凹凹の形成による表面 積の増加に伴い密着力が増大することが知られてい る(15). そこで, この観点から界面密着力の変化を検討 するために, 本研究で用いた各試験片のブラスト処理 に伴う表面積増加率を求めることとした. 表面積増加 率の評価法としては，まず A series および B series の R 部横断面上の表面凹凸部分をレーザ顕微鏡によ り一定距離 $(650 \mu \mathrm{m})$ 観察し, 得られた画像から画像解 析により表面長さ $L$ を求め, 次に C series(鏡面状態) に関して求めた同様な表面長さを $L_{m}$ とし, 次式によ り表面積の増加率 $P$ を求めた。

$$
P=\left(\frac{L}{L_{m}}\right)^{2} \times 100
$$

各シリーズについて 100 点測定した結果を図 10 に 示す.

これより、ブラスト処理による表面積増加率は $\mathrm{A}$ series >B seriesの順で大きいことがわかる.つまり， 物理吸着力の観点加も皮膜-基材の界面密着性は $\mathrm{A}>\mathrm{B}>\mathrm{C}$ series の順で強いと考えられる.

以上のことから, 基材そのものの疲労強度は基材表 面が粗いほど低いのに対し，逆に溶射材では，基材表 面が粗いほど破壊起点部の疲労強度が高くなる理由 は, 皮膜-基材界面での密着力が強く, 疲労負荷過程に

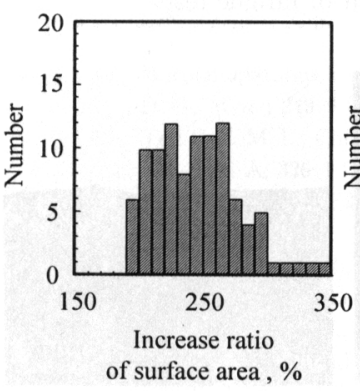

(a) A series

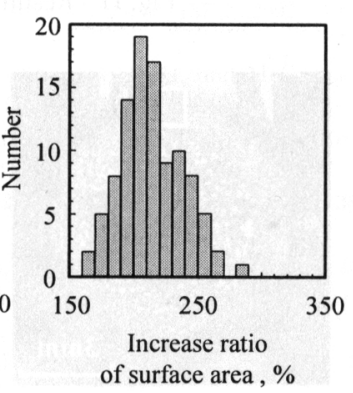

(b) B series
Fig. 10 Increase ratio of surface area 
おいても局所的に皮膜-基材界面が強固に密着してい る箇所がより多く形成されているためであるといえ る.

\section{$3 \cdot 4$ 自溶合金溶射部材の疲労強度に及ぼす基材表} 面粗さの影響(長時間フュージング) $3 \cdot 3$ 節では, 比較的短時間でフュージングを施したため, 基材一皮 膜界面に形成される拡散層が薄く, 界面密着力が十分 でないため，界面はく離形の疲労破壊が起こり，その 結果期待するほどの疲労強度向上は見られなかった。 これまでの研究(13)(14)によれば, 長時間のフュージン グを施し, より厚い拡散層を形成すると, 疲労負荷過 程ではく離が起こり難くなることが明らかとなってい る.そこで $3 ・ 4$ 節では, 長時間のフュージングを施 し，より厚い拡散層を形成した場合について，溶射材 の疲労特性に及ぼす基材表面粗さの影響をさらに調べ た。

まず真空炉中で長時間フュージングを施した試験片 についての疲労試験結果を図 11 に示す。図 11 の緃軸 は，皮膜と基材を同一材とみなして，皮膜部を含んだ 試験片直径から計算した表面公称曲げ応力を表してい る.

図 11 より，B+ $\operatorname{spray}(\mathrm{V})$ seriesおよび $\mathrm{C}+$ spray (V) series では, 基材に比べて 280\%もの著しく大き

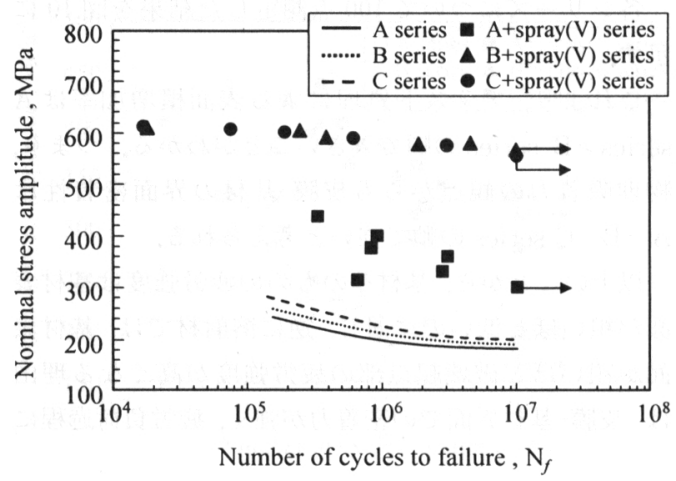

Fig. 11 Result of fatigue tests

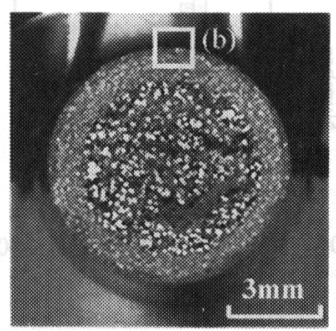

(a) Fracture appearance

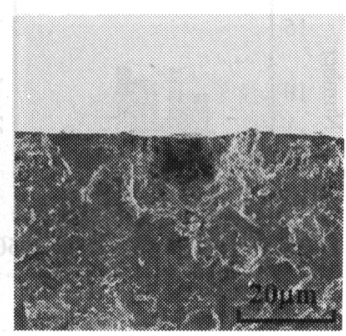

(b) Crack initiation site
Fig. 12 Fracture surface of $\mathrm{C}+$ spray (V) series
な疲労強度の向上が確認できるのに対し，A+spray (V) series では, $3 \cdot 3$ 節で示した $A+\operatorname{spray}(\mathrm{I})$ series と同程度の疲労強度の改善にとどまっていることがわ かる、この要因を検討すべく各シリーズの破壊起点部 に注目して破面観察を行った結果, B+spray $(\mathrm{V})$ series, C $+\operatorname{spray}(\mathrm{V})$ seriess $と, A+\operatorname{spray}(\mathrm{V})$ series との間には, 次のような明確な破壊形態の相違が確認 された。まず, 疲労強度向上幅の著しい B+spray (V) series およびC+ $\operatorname{spray}(\mathrm{V})$ series では，ともに 図 12 にその代表例を示すような皮膜表面の溶射欠陥 を破壊起点とする皮膜表面形の疲労破壊であることが 確認された。

これに対し $\mathrm{A}+\operatorname{spray}(\mathrm{V})$ seriesでは, $3 ・ 3$ 節に示 したと同様な界面はく離形の疲労破壊を生じているこ とが明らかとなった，図 11 の疲労試験結果をそれぞ れの破壊起点部に働く応力で整理し直した結果を

図 13 に示す.

図 13 からも, B+ $\operatorname{spray}(\mathrm{V})$ series および $\mathrm{C}+$ spray (V) series の疲労強度は, 基材に比べて著しく向上し ていることが確認できる。 また,このような皮膜表面 形破壊が生じる場合には，溶射材の疲労特性に及ぼす

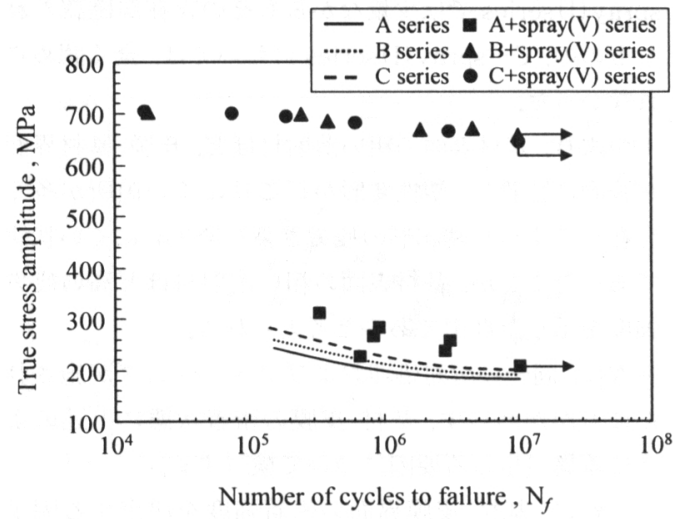

Fig. 13 Result of fatigue tests

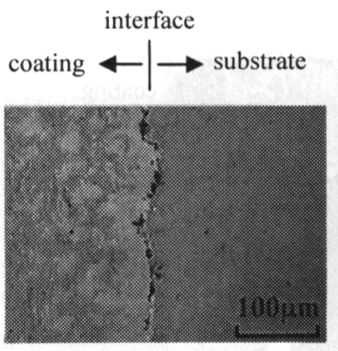

$\mathrm{A}+\operatorname{spray}(\mathrm{V})$ series

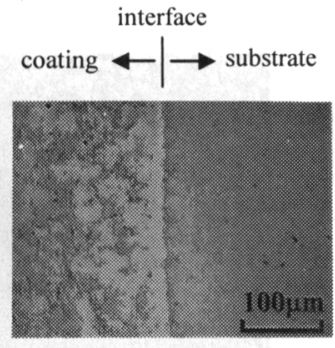

$\mathrm{C}+\operatorname{spray}(\mathrm{V})$ series
Fig. 14 SEM observations of the interface 


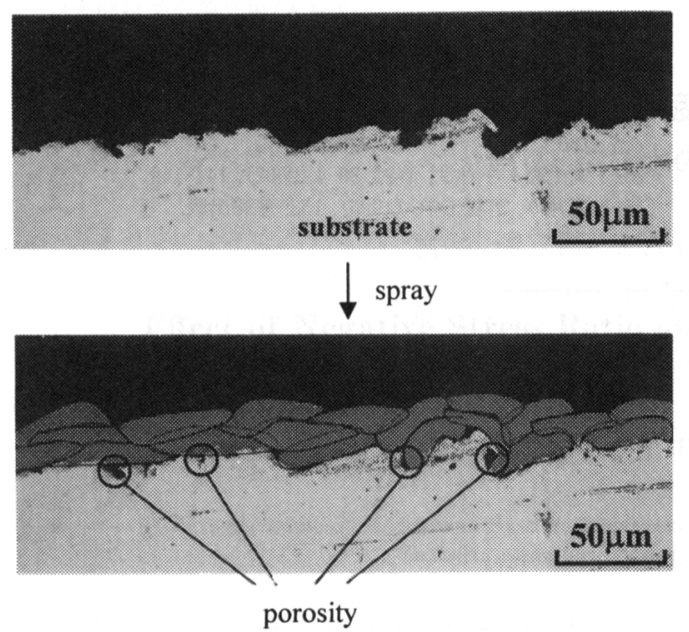

Fig. 15 Schematic illustration of the interface

基材表面粗さの影響はほとんど認められないことがわ かる.一方, 界面はく離形破壊を起こす $\mathrm{A}+\mathrm{spray}$ (V) series では, $3 ・ 3$ 節で述べた短時間フュージング の場合 $(\mathrm{A}+\operatorname{spray}(\mathrm{I})$ series $)$ と同程度の疲労強度にと どまっていることがわかる.

最後に, 最も基材表面粗さの粗い $\mathrm{A}+\operatorname{spray}(\mathrm{V})$ seriesでのみ, 界面はく離形の疲労破壊が生じた原因 を調べるため, 各シリーズについて繰返し応力を負荷 する以前の状態での横断面の界面近傍を SEM により 詳細に観察した. A+ spray $(\mathrm{V})$ seriesおょびC+ spray $(V)$ series を例として観察結果を図 14 に示す.

図 14 より, 疲労負荷過程ではく離を生じた A十 spray $(\mathrm{V})$ series における界面には，それに沿って数多 くの空げきが確認されるのに対して, C $+\operatorname{spray}(\mathrm{V})$ seriesでは空げきがほとんど存在しないことがわか る.また,フュージングを施していない As sprayed 状態で同様な観察を行ったところ, 図 14 と同様な結 果が得られたことから, かかる空げきは, 溶射処理の 段階で形成されていたことがわかる。このように基材 表面が粗い場合に，溶射処理時に空げきが形成される 理由は図 15 のように説明される。ここで，上図は基 材表面の実際の横断面形状であり，また下図は，かか る表面に溶射粉末を積層した状態を模式的に表してい る。図 15 からわかるように, A series では非常に粗 い表面形状のため, 半溶融状態の溶射粉末が表面凹凸 部分に入り込めない箇所が多く形成され，このように して界面近傍に形成された空げきが, フュージングに よっても除去されずに残存する。このように残存した 空げきが疲労負荷過程で界面はく離を導き，さらには く離によって露出した基材表面を起点として疲労き裂
が発生, 進展したため, $\mathrm{A}+\operatorname{spray}(\mathrm{V}) \operatorname{series}$ のみ界面 はく離形の疲労破壊が生じたと考えられる. 以上よ り，基材に対する適度の粗面化は界面密着性の観点か ら溶射材の疲労強度の改善に有効であるものの, 過度 に粗い基材表面を形成することは，溶射処理時に皮 膜-基材界面に空げきを誘起して, 溶射部材の疲労強 度の改善を頭打ちにしてしまうといえる。

\section{4. 結 論}

自溶合金溶射部材の疲労強度に及ぼす基材表面粗さ の影響を明らかにする目的で，異なる 3 種類の表面粗 さを有する基材 ( $\mathrm{S} 35 \mathrm{C}$ )に対し, $\mathrm{Ni}$ 基自溶合金を溶 射し, さらに異なる長短 2 種類のフュージングを施し た試験片を準備し，これらについて回転曲げ疲労試験 を行うとともに, 破壊メカニズムを詳細に観察するこ とにより，以下に示す結論を得た。

（1）短時間フュージングを施した場合，基材表面 粗さによらず，すべての溶射材は界面はく離形の疲労 破壊を示した。この場合, 基材表面粗さの粗い溶射材 ほど, 高い疲労強度を示した。これは, 基材表面粗さ が粗いほど，（i ）機械的かみつき力，（ii）表面積増大 に伴う物理吸着力が大きく, これにより界面において 疲労負荷過程においても, 皮膜一基材が強固に密着し た箇所が多く残存するためである.

（2）界面密着力が強く, 皮膜表面形の破壊を示す 溶射材の場合，疲労強度に及ぼす基材表面粗さの影響 は現れない.

（3）過度に粗い基材表面を形成した場合，溶射時 に基材一皮膜界面近傍に多くの空げきが残存すること になり，その結果界面はく離形の疲労破壊が起こり， 疲労強度向上にはつながらない.

\section{文献}

（1）福本昌宏・高村康雄・梅本実・岡根功, 溶接学会論文集, No. 8-4 (1990), 450-456.

(2) Planche, M. P., Normand, B., Liao, H., Rannou, G. and Coddet, C., Surface Coat. Technol., 157-2 (2002), 247256.

(3) Wirojanupatump S., Shipway, P. H. and McCartney, D. G., Wear, 249-9 (2002), 829-837.

(4) Ted Guo, M. L., Chiang, C.-H. and Tsao, C. A., Mater. Sci. Eng. A, 326-1 (2002), 1-10.

（5）田尻登志朗 - 渡部正氣 - 峪田宜明 - 山本誠司, 溶射, $\mathbf{1 3 6}$ 3 (1999), 137-144.

(6) McGrann, R. T. R., Greving, D. J., Shadley, J. R. Rybicki, E. F., Kruecke, T. L. and Bodger, B. E., Surface Coat. Technol., 108-109 (1998), 59-64.

(7) Hoffman, M. E. and Hoffman, P. C., Int. J. Fatigue, 23 (2002), 1-10.

（8）黄貞雄・小川武史, 材料, 45-8 (1996), 927-932

（9）小茂鳥潤 - 屈寧双 $\cdot$ 清水真佐男 - 白井勝之, 機論, 62-604, 
A (1996), 2687-2692.

（10）竹下友之・佐藤伸幸 - 小茂鳥潤 - 清水真佐男 - 白井勝之, 溶射, 34-2 (1997), 84-90.

（11）呉定錫 - 小茂鳥潤・清水真佐男, 溶射, 37-4（2000）, 166174.

（12）吳定錫・李秉濠 - 小茂鳥潤 - 清水真佐男 - 白井勝之，機 論, 67-656, A (2001), 749-756

（13）呉定錫 - 小茂鳥潤 - 清水真佐男, 溶射, 38-2 (2001)，65-
72.

（14）曙紘之・伊藤量平・福本昌宏・小茂鳥潤 - 清水真佐男, 機論, 70-694, A (2004), 843-849.

（15）福本昌宏・村上裕昭・岡根功，溶射， 31-1 (1994)，130136.

（16）丸山徹 - 小林武, 溶射, 39-4 (2002)，144-149.

(17) 蓮井淳, 溶射工学, (1996), 153, 産報出版. 